\title{
A Model of Electronic Document Management System for Limited Partnership
}

\author{
Faiqunisa, Eko Nugroho, Paulus Insap Santosa \\ Jurusan Teknik Elektro dan Teknologi Informasi FT UGM \\ JIn. Grafika 2 Yogyakarta 55281 INDONESIA \\ Email: faiqunisa@mti.gadjahmada.edu,nugroho@mti.ugm.ac.id, insap@mti.ugm.ac.id
}

\begin{abstract}
Both types of documents, electronic and non-electronic are a major component supporting activities. In addition to the documents, communications capabilities to employees and managers effectively with other stakeholders are one of the important key achievements of organizational goals. $L P$. $X Y Z$ is one of the Consultants in the field of Information Technology, but the storage and management of electronic documents and archives themselves carried on a server without a management information system, so that records and electronic documents have not been properly managed. This study makes modeling system includes document management of process models, data models and interface models to suit the needs of the $L P . X Y Z$ administration in organizing activities, such as enterprise document management, web content management, project management and communication management of work, so the management information system may be supporting the business activities and operations of $L P$. $X Y Z$.
\end{abstract}

Keywords: corporate documents, administration, process modeling, data modeling, modeling interface

\section{Introduction}

Documents to be one important factor in measuring the level of achievement of the activities organized in the company. The importance of the information in these documents can be used as a reference in decision making, policy formulation, planning, regulation, monitoring or monitoring performance and evaluating the activities and so.

A document produced from a process activity is one of the important information in business. Such information is needed for ministry purposes and internal purposes. The progress of a business depends on decisions taken, which is supported by the accuracy, completeness and speed in presenting the information.

In addition to the document as a main component to support activities, the ability of communication to employees and managers effectively with other stakeholders is one of the important key achievements of organizational goals. Many of the benefits of good communication, as will be able to anticipate problems, make the right decisions, to coordinate the flow of work, building good relationships, etc [1]. In the absence of effective communication, the percentage of people will misunderstand and misinterpret the information submitted will be huge. Therefore, documents and communication is an important factor in the organization.

This study will make the management of document modeling system includes a process model, data model and the interface model to suit the needs of the limited partnership (LP) XYZ administration in organizing activities, such as enterprise document management, web content management, project management and communication management of work, so the management information system may be supporting the business activities and operations of LP. XYZ and expected by the design model of an electronic document management system, it can bridge the problems that occurred and led to the achievement of expected conditions.

\section{Research Method}

Stages of research conducted shown in Figure 1. 


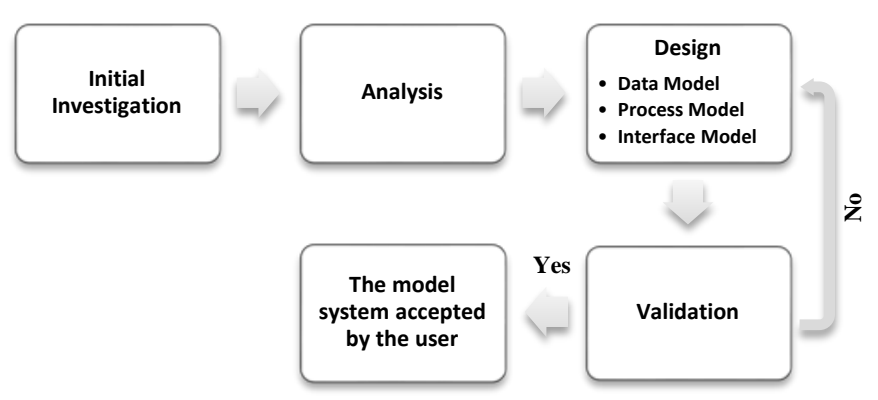

Figure 1. Research stage

\subsection{Initial Investigation}

The research started from studying the activities of LP. XYZ and identify problems, opportunities and objectives to be achieved. Beginning with a look at what is happening in the organization and ultimately determine the issues. Followed by identifying goals that are part of an important component in the development of the system. What should be done to identify the purpose is to find the things that were done by LP. XYZ and see aspects of information system applications to help the organization to achieve its goals by outlining the problem or the specific opportunities. This initial investigation activities conducted by interviews and field observations.

a) Learning Activities of LP. XYZ

Early stages of an investigation initiated by studying administration at LP. XYZ. LP. $X Y Z$ is one of the Consultants in the field of Information Technology. There are 2 (two) types of activities undertaken by the LP. XYZ, the external and internal. For external events, there are 2 (two) types of projects, namely projects undertaken by client requests and project auctions held by the government, while the internal projects such as products produced by one of the department in which the product is not based on client request.

b) Identification of Problems

There are several problems that underlie the modeling of electronic document management systems, namely the storage of electronic documents, web content storage and communication issues, good communication about the project, as well as other communication.

For the administration, current LP. XYZ has only 1 (one) storage for storing electronic documents. The storage media does not have information systems in it to document settings and the storage is offline. Currently, preparations for the opening of branch offices is being carried out by LP. XYZ and for the distribution of documents among employees from branch offices and branch offices still use e-mail. In the administration, there is no SOP (Standard Operating Procedure) governing document storage. This resulted in difficulties in search a document.

In the electronic document storage server owned by LP. XYZ, in which also store web content is a reference, both the product and the product yield of the projects handled by the LP. XYZ. In the electronic document storage server is already contained web application server, web server, but has not been utilized to the maximum. This is due to the lack of a web content management application is run, so that the data processing is still done manually.

In the handling of the project, the application is currently used by LP. XYZ is the facility to communicate group on Facebook.

c) Identify Opportunities and Goals

Opportunities for companies to achieve competitive advantage and strategic advantage is the use of information systems refers to the use of appropriate information and quickly and change all the data into a database with a standard interface such as a web browser, making it possible to share data accurately and quickly for the sake of coordination or communication much easier.

From the facts described above, it can be a conclusion that transform data into a database and build an information system that can provide the distribution of feature information accurately and quickly became a destination in the construction of the model, in 
addition to the model is also expected to address the issue of corporate communications, then it can provide a distinct advantage for the company.

\subsection{Analysis}

The analysis begins by determining and setting the terms of the information for users involved. The terms are taken from the examination of the data obtained from interviews and field observations. Followed by analyzing the needs of the system and results in the form of data and process models. The process model uses data flow diagrams to prepare input, process and output of the system in the form of structured graphs. For data model, design files or databases that can store data that is needed, because the basis of well-structured data is the basis for all information systems.

a) System analysis

Based on the identification of issues, opportunities and objectives, an analysis of the electronic document management system to be designed. The information system will be designed to answer the problems that exist in the LP. XYZ documents including issues such as web content and communication, especially about the project. Therefore, the following needs of the module in the electronic document management system to be designed:

1) Management of the project: task accommodate any project work, in which the task will be given to workers can be monitored, including deadlines;

2) Forum: accommodate all communication within the company either associated with the project or not;

3) Web content management: accommodating-content web content contained in a storage medium that is being, or has been fortofolio done by LP. XYZ;

4) Document management: accommodating database of company documents in order to more easily share documents and information, including in it also features access rights to documents. Facilities contained in the customized document management with document management on a local hard drive, such as: new folder, copy, delete, move, rename, view, edit and add to the upload and download. To view and edit facilities, the system can only support a few documents only, such as text document, microsoft word document; microsoft excel document; adobe acrobat document, as well as the file associated with the web content.

b) User Analysis

An electronic document management system is a backend information systems that will be used by the heads and employees in the LP. XYZ. Because the electronic document management system is an information system that are in the scope of the administration, and therefore there would be only 2 (two) components of the user who can use electronic document management system, namely Admin and Member. Admin user can give different permissions to different users Member in accordance with the duties and position of the user is. Categorized as a user other than Admin Member Admin has a feature due to grant different for each user in the electronic document management system. Users other than Admin be the Member with the goal of flexibility, so that in case of such things as change of position, Admin only need to change the permissions of the user without the need to register a new user with a new title.

c) Task Analysis

From the analysis of the user giving the result that there are 2 (two) components of the user who will use electronic document management system, the Admin and Member. Because the Member shall have the right of access is different, it will explain some of the duties of each user type. The explanation of the duties of each user type is shown in Table 1. 
Table 1. Task Description Each User

\begin{tabular}{cl}
\hline Type of User & \multicolumn{1}{c}{ Task } \\
\hline Admin & $\begin{array}{l}\text { 1. Grant permissions to user } \\
\text { 2. Take full responsibility for management of the modules contained in the } \\
\text { system }\end{array}$ \\
$\begin{array}{c}\text { 1. Managing documents in accordance with the right to access these documents } \\
\text { (document management module) } \\
\text { Marketing (Member) }\end{array}$ & $\begin{array}{l}\text { 2. Communicating about a few things, both on task work and other things } \\
\text { (modules and project forums) }\end{array}$ \\
$\begin{array}{l}\text { 1. Managing documents in accordance with the right to access these documents } \\
\text { (document management module) }\end{array}$ \\
$\begin{array}{l}\text { 2. Managing web content (web module content) } \\
\text { 3echnical Division } \\
\text { (Member) }\end{array}$ \\
(modules and project forums)
\end{tabular}

\subsection{Validation}

Phase model validation is done by giving a demo system modeling results to employees at LP. XYZ of the next stage of the interview to the employee. Interviews were conducted by providing the following questions:

a) Is the Electronic Document Management System modeling can be accepted to help the performance of the employees in the LP. XYZ infomasi in terms of distribution, communication, document management and web content?

b) What are the advantages of this model is Electronic Document Management Systems?

c) What are the drawbacks of the model's Electronic Document Management System?

d) What advice can be given as input to the modeling of this Electronic Document Management Systems?

\section{Results and Discussion}

\subsection{Research Results}

a) Process Modeling

In documenting the process can be done by using a DFD (Data Flow Diagram) [2], but it also as in [3] describes DFD model of a system because it emphasizes the aspect of the process.

Besides DFD, to document the process, it is necessary UML (Unified Modeling Language) with Use-Case Diagram. Use-case diagram is a diagram showing a series of usecases and actors and their relationships occurring, this handy diagram to illustrate the use-case static picture of a system/software. This diagram was instrumental in setting up and modeling behavior (the emphasis is on what is done the system, not how the system). A use-case represents an interaction between the actors with the system [4].

Use-case diagram conducted shown in Figure 2-10.

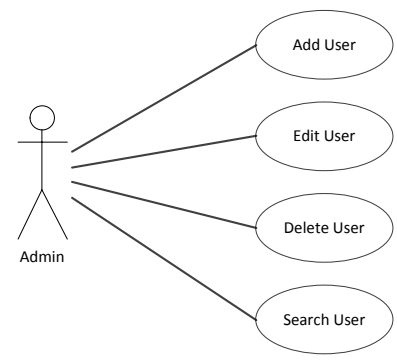

Figure 2. Use-case diagram management user

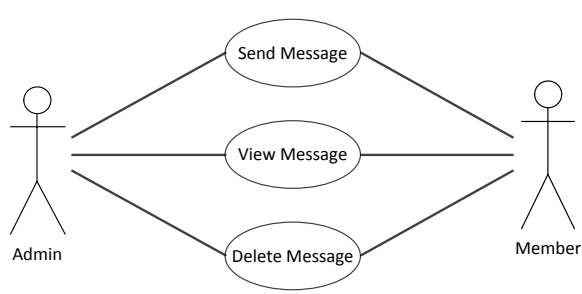

Figure 3. Use-case diagram message 


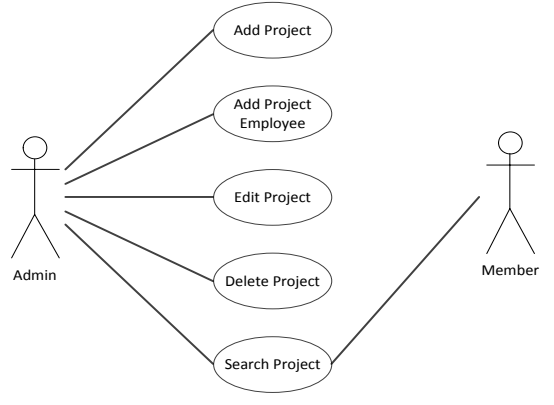

Figure 4. Use-case diagram management project

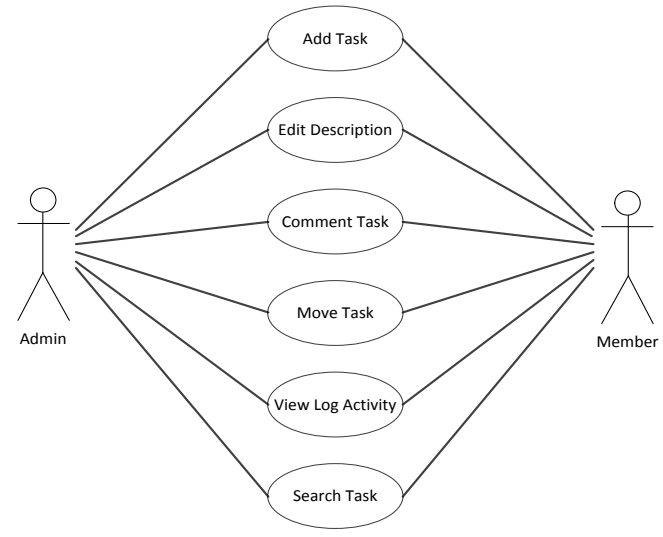

Figure 5. Use-case diagram manajement task

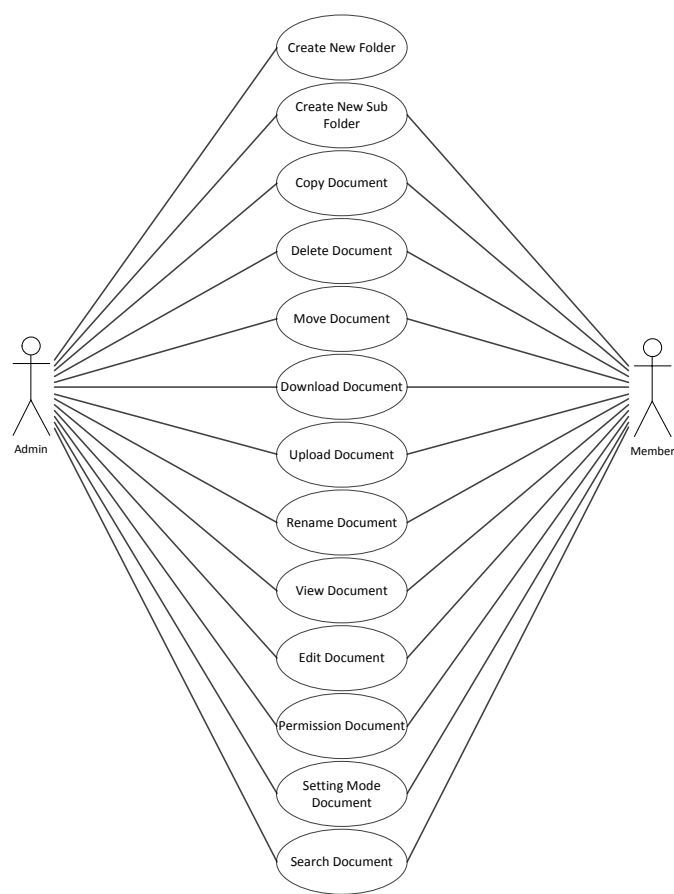

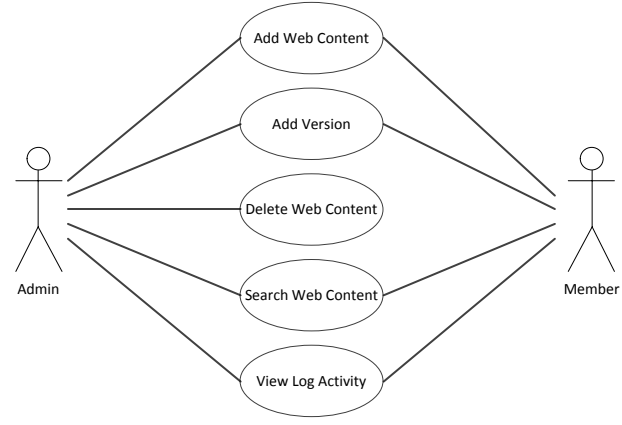

Figure 7. Use-case diagram management web content

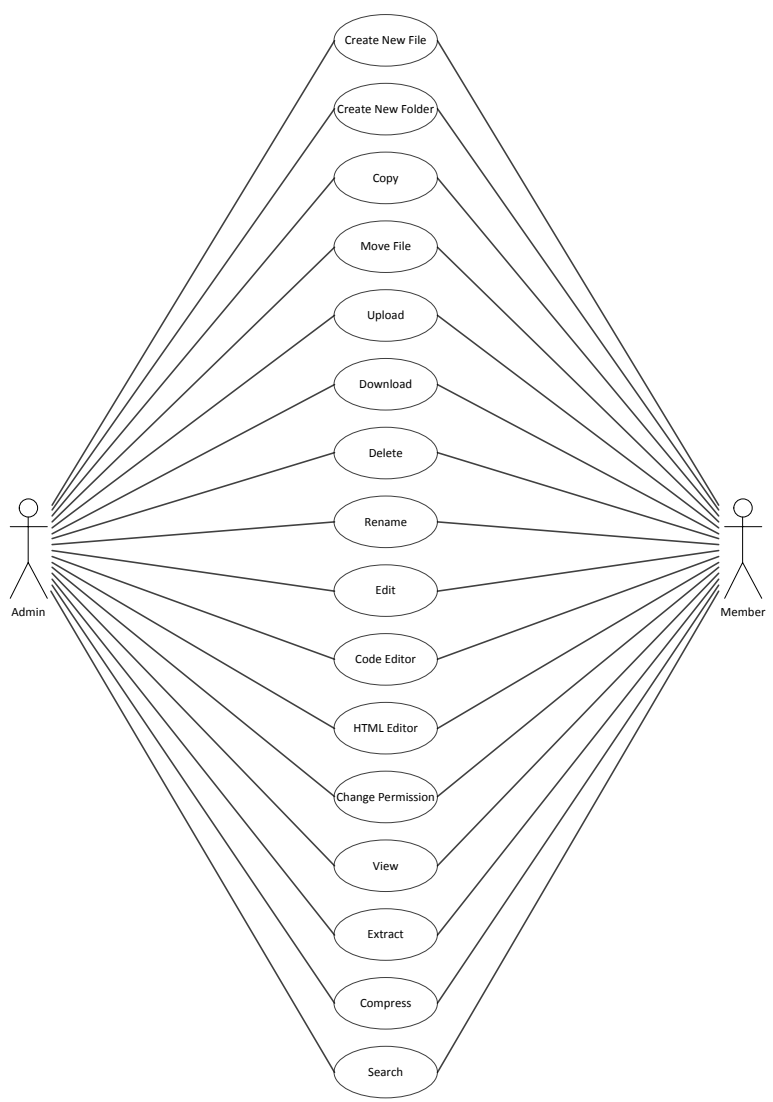

Figure 8. Use-case diagram file manager web content 
Figure 6. Use-case diagram manajement document
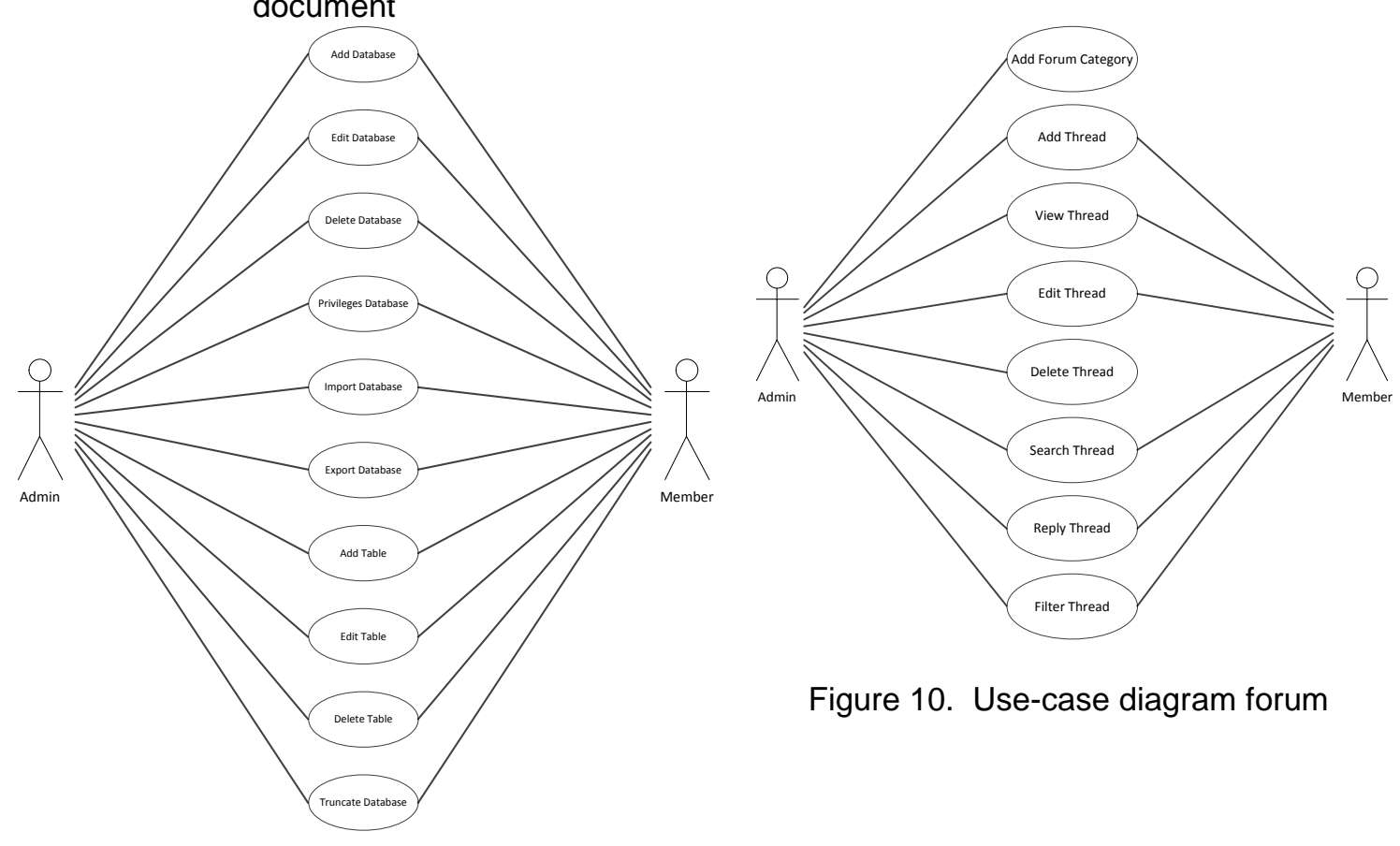

Figure 10. Use-case diagram forum

Figure 9. Use-case diagram database management web content

Context diagram is a view, which includes the basic inputs, general system and output. Context diagram is the highest level in a data flow diagram and contains only one process, indicating the overall system, but does not include data storage [5].

In this study, a context diagram describes the system in general about the Electronic Document Management System has to offer can be seen in Figure 11.

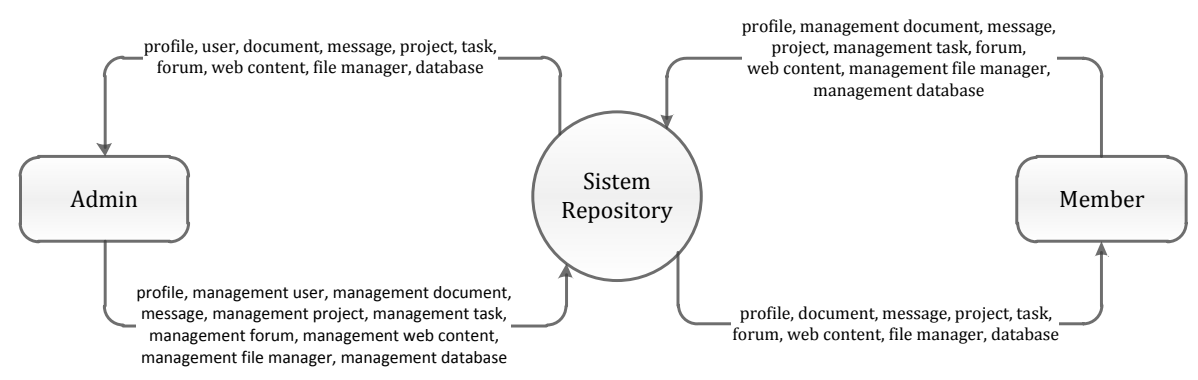

Figure 11. Context diagram

Data Flow Level 0 Diagram is a context diagram and the development of each process are given integer numbers. In level 0 diagram describes the main processes that occur in the administrative process, ranging from the storage of electronic documents, web content storage and communication of project management and communication. In the level 0 diagram, there are 10 main processes include the login process, so be specific [5]. And an overview level 0 diagram on Electronic Document Management System offered can be seen in Figure 12. 


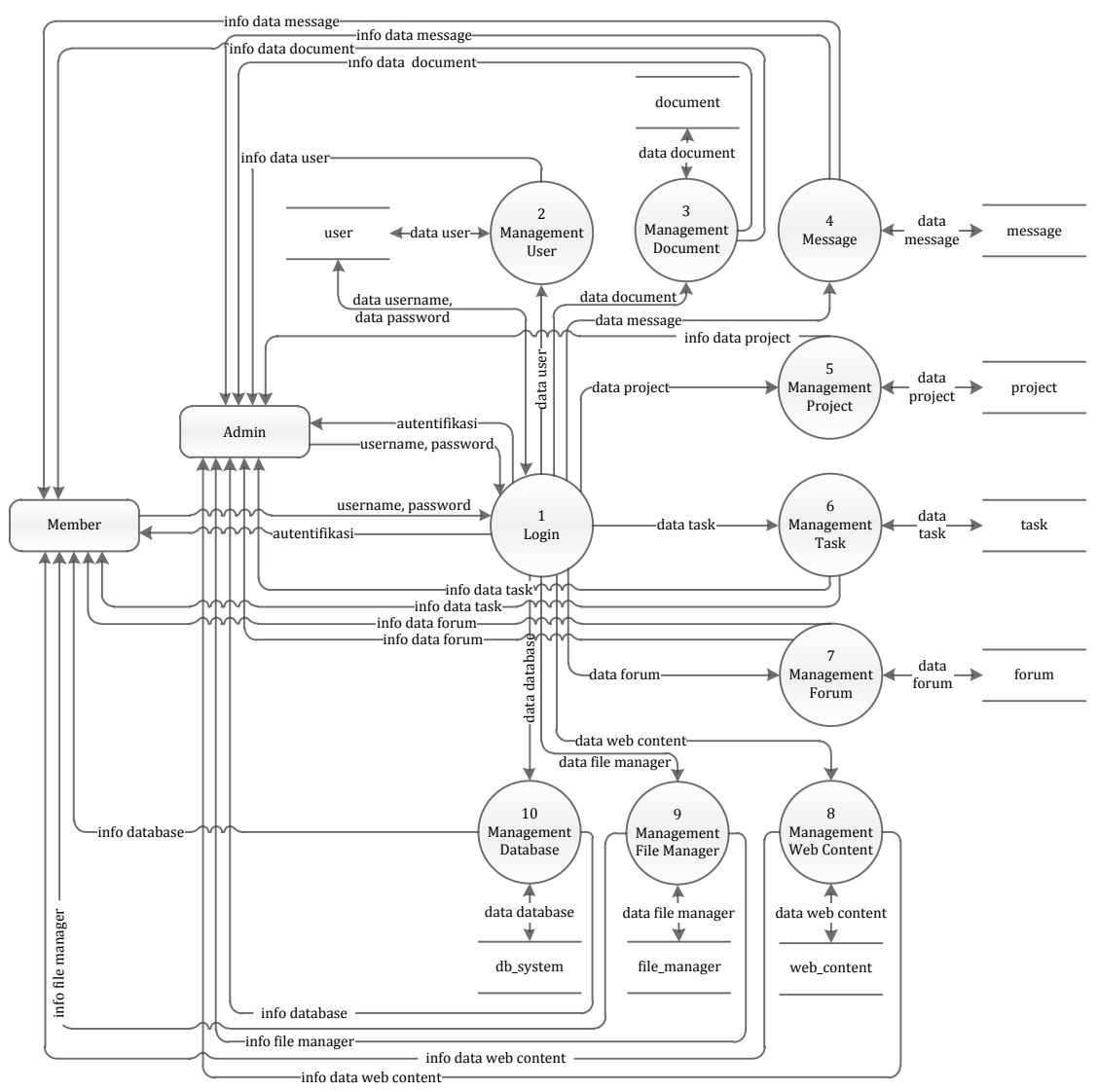

Figure 12. Data flow level 0 diagram

\section{b) Data Modeling}

According to McLeod as in [2], ERD (Entity Relationship Diagram) can be used in modeling the data because it shows the entities and relationships or relationships between entities such. In this study, ERD which displays tables that represent entities and relationships between entities in the Electronic Document Management System has to offer, in which the Electronic Document Management System includes four modules that handle document management including web content and communication, especially regarding the project.

Electronic Document Management System LP. XYZ consists of 19 tables, namely:

1) User table: id_user, username, password, nama, jabatan, email user, tempat_lahir, tanggal_lahir, no_hp, alamat and file_LP;

2) Project_task table connect with project_task_comment table and project_task_permission_user table. Project_task table: id_task, nama_task, deskripsi_task, modified_by and modified date;

3) Project_task_commenttable: id_comment_task, id_user, id_task, comment, tanggal and status:

4) Project_task_permission_usertable: id_task_permission_user, id_user, id_task and status;

5) Thread table connect with thread_kategori table and thread_comment table. Thread table: id_thread, id_user, id_kategori_thread, judul_thread, isi_thread and tanggal;

6) Thread_kategori table: id_kategori_thread and nama_kategori;

7) Thread_comment table: id_comment, id_user, id_thread, comment and tanggal;

8) Dokumen table connect with doc_folder table. Dokumen table: id_dokumen and nama_dokumen;

9) Doc_folder table: id_folder_doc, id_dokumen, nama_folder, modified_by, modified_date and permission mode;

10) Doc_folder_permission_user table: id_permission_user, id_user and id_folder_doc; 
11) Doc_file table connect with doc_file_permission_user table. Doc_file table: id_file_doc, id_folder_doc, nama_file, modified_by, modiffied_date and size;

12) Doc_file_permission_user table: id_file_permission_user, id_user and id_file_doc;

13) Projecttable connect with project_permission_usertable andproject_versiontable. Project table: id_project, nama_project, deadlineand keterangan;

14) Project_permission_usertable: id_project_permission_user, id_user and id_project;

15) Project_versiontable: id_version, id_project and version;

16) Web_contenttable connect with web_content_logtable and project_versiontable. web_content_logtable: id_web_content, id_project, id_version, image, user_database, password_database, namāddatabase, user_control_panel and password_control_panel;

17) Web_content_logtable: id_log_web_content, id_web_content, id_user, nama_user, tanggal_log and aksi;

18) Messagetable: id_message, keterangan_dari, keterangan_untuk, isi_message and tanggal;

19) Log_sistemtable: id_log_sistem, id_user, log_date, aksi and nama_user.

c) Interface Modelling

Electronic Document Management System is divided into 4 (four) main modules, namely project management, forums, web content management and document management. To log into the system, the user is required to perform the first login. After making the login process, the user will enter the home page where a dashboard on the home page of the project management module. Project management module serves as a communication companies such as giving the task to the employee work for each project, sending messages to other users, job tracking task.

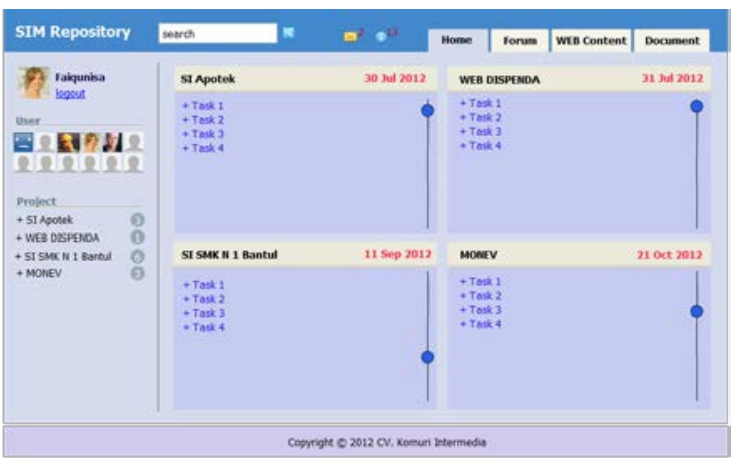

Figure 13. The interface design of the dashboard page

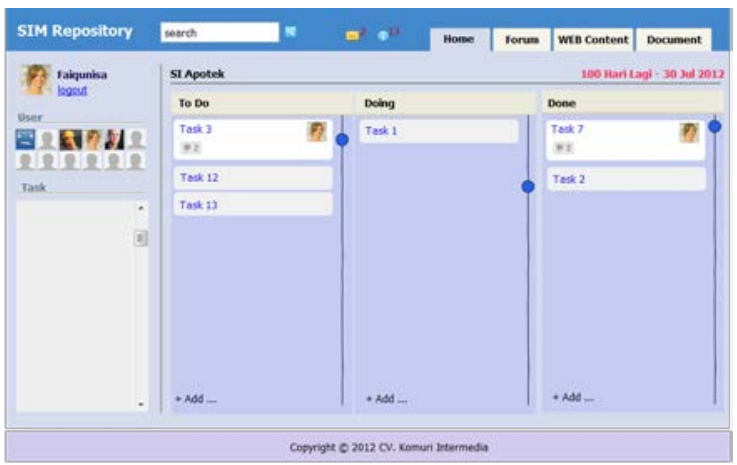

Figure 14. The interface design of the project page

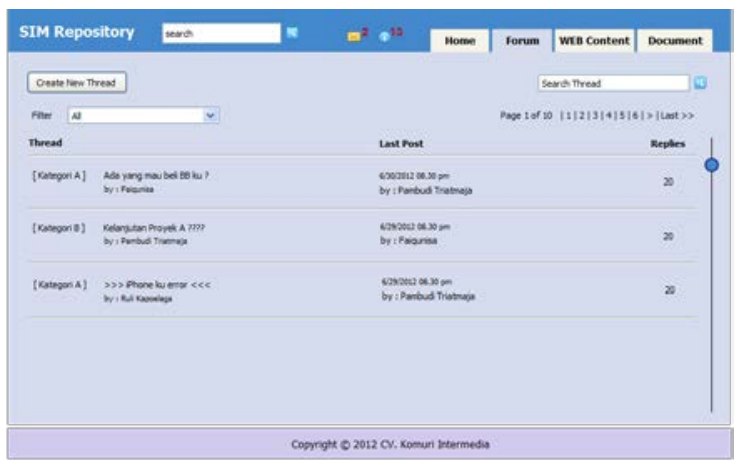

Figure 15. The interface design of the forum page

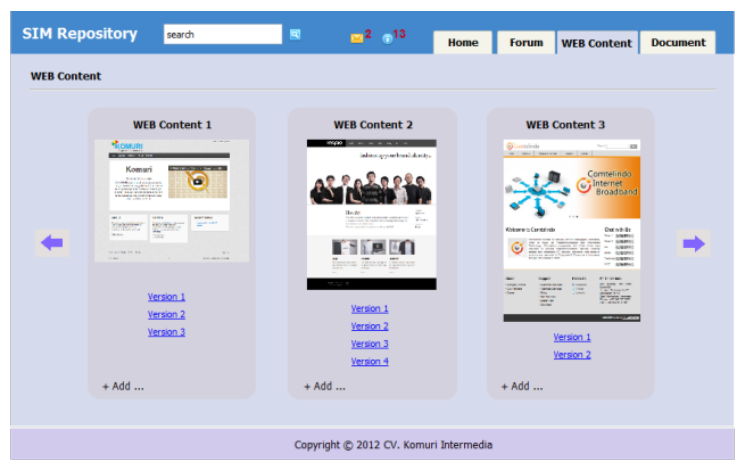

Figure 16. The interface design of the web content page 


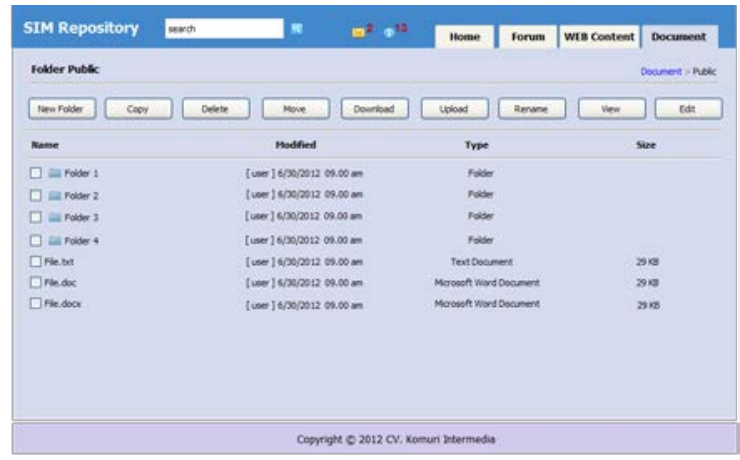

Figure 17. The interface design of the document page

\subsection{Discussion}

Making Electronic Document Management System modeling begins with the initial investigation activities filled with learning activities and the activities identified issues contained in the LP. XYZ, identify opportunities and goals to be achieved. After that proceed to analyze the system, the user and the task in which the results of the analysis will be used as the basis for analyzing system requirements. The results of the analysis of such data models, process models and interface models. Once the data model, process model and interface model is generated, the next process is validation by the user where the validation was intended to see whether the system model is acceptable or not before the model is implemented by the user.

Stages of process modeling using UML and DFD, with preliminary results in the form of UML use-case diagram and preliminary results in the form of DFD context diagram. Developed a context diagram become diagram level 0 to produce 10 key process in the electronic document management system. These processes are user management, document management, message, project management, task management, forum management, web content management, file manager management dan database management. Each process in the level 0 diagram developed into a child who is a breakdown of each process in the level 1 diagram.

At this stage of the modeling data consists of the manufacture of ERD, where ERD generate relations between tables. Tables were produced through the process of ERD were 19 tables. At this stage of the modeling interface used 2 (two) software, the Pencil and GUI Design Studio. Pencil is used to design the user interface or the interface of the electronic document management system modeling graphically. Pencil used to create the application design, dialogue and components, while the GUI Design Studio is used to combine the existing designdesign to make the design more information or to make modeling more interactive interface.

Making electronic document management system modeling has a 4 (four) main modules, namely the project management, forums, web content management and document management. 4 (four) modules addressing issues of distribution of information, communication and document management also includes web content.

\subsection{Validation}

Validation of the model is the final stage of the development of a model system, in which the validation was intended to see whether the system model is acceptable or not before the model system is implemented in the LP. XYZ. Validation is done by the user who will be using Electronic Document Management Systems, in which the user is an employee of LP. XYZ with different educational background. Stages of validation begins by first presenting a model of the system and then be interviewed about the advantages, disadvantages and suggestions for models of this system. Interviews conducted for 8 (eight) of the respondents by asking questions about the Electronic Document Management System model is acceptable or not, but it also polled respondents about the advantages, disadvantages and suggestions for models of this Electronic Document Management Systems. List of respondents can be seen in Table 2. 
Table 2. List of Respondents

\begin{tabular}{cccc}
\hline Gender & Educational Background & Position & $\begin{array}{c}\text { Acceptance } \\
\text { Model System }\end{array}$ \\
\hline Female & Industrial Engineering & Business \& Marketing & Yes \\
Female & Economics and Accounting & Administration \& Finance & Yes \\
Male & Politics and Government & Human Resource & Yes \\
Male & Informatics & Business \& Marketing & Yes \\
Male & Informatics & Administration \& Finance & Yes \\
Male & Informatics & Programmer & Yes \\
Male & Informatics & Programmer & Yes \\
Male & Informatics & Programmer & Yes \\
\hline
\end{tabular}

According to the results of the validation, the electronic document management system model created is acceptable with some suggestions submitted by respondents. In addition to questions about the acceptance of the system model, some questions were asked to respondents who have educational background of informatics, weaknesses and suggestions for models of Electronic Document Management Systems. Here are the advantages of Electronic Document Management System model based on the results of interviews:

a) Can answer the problem of information distribution and documents still use features Facebook group and email;

b) The system combines the 4 (four) features a 1 (one) system of interconnected;

c) The system combines the to do list, portfolio and corporate documents into 1 (one) system;

d) Systems facilitate employee performance.

These weaknesses of the Electronic Document Management System model based on the results of interviews:

a) System is less than the maximum for the mobile employee, and

b) Need for SOP (Standard Operating Procedure) in the preparation/storage of documents.

Following suggestions made by the respondents for the Electronic Document Management System model based on the results of interviews:

a) Need to perform additional verification feature of superiors on the project management module in order to validate that the work was actually completed;

b) There needs to be additional activity log feature in the document management module that can be control;

c) There needs to be additional features added to the document version;

d) Need the addition of chat module;

e) Need a description of the information for each project;

f) Need for additional features to edit permissions and modes on the document;

g) Need the addition of push mail feature for each notification.

\section{Conclusion}

Modeling Electronic Document Management System has a 4 (four) main modules, namely the project management, forums, document management and web content management. There are 10 (ten) in the Electronic Document Management System model that includes user management, document management, messaging, project management, task management, forum management, web content management, file manager management and database management and there are 19 (nineteen) table the database. There are 2 (two) components of the user who can use electronic document management system, namely Admin and Member, where Admin can give different permissions to different user Member for each module in accordance with the duties and position of the user is. In the system development life cycle, modeling the Electronic Document Management System proposed is at the design stage, so it still requires some subsequent stage in the development of information systems before becoming a full information system and can be used. Evaluation of Electronic Document Management Systems modeling has done by the validation by the user and user validation results by saying that the Electronic Document Management System model acceptable. Based on the evaluation of the user, Electronic Document Management System model proposed has 
the advantages of ease of employee performance problems such as answering the distribution of information and documents, and the Electronic Document Management System model incorporates 4 (four) features a 1 (one) that are connected to the system to do list, portfolio, company documents and forums. Based on the evaluation of the user, Electronic Document Management System model proposed has the drawback, which is less than the maximum system model for mobile employees, and the need for SOP (Standard Operating Procedure) in the preparation/storage of documents.

\section{References}

[1] Sukoco BM. Manajemen Administrasi Perkantoran Modern. Jakarta: Erlangga. 2007.

[2] Mc Leod R. Management Information Systems. Seventh Edition. New Jersey: Prentice Hall. 1998.

[3] Sutabri T. Analisa Sistem Informasi. Yogyakarta: ANDI Offset. 2004.

[4] Booch G, Jacobson I, Rumbaugh J. The Unified Modeling Language User Guide. Second Edition. Boston: Addison-Wesley. 2005.

[5] Kendall KE, Kendall JE. Systems Analysis and Design. Fifth Edition. New Jersey: Prentice Hall. 2002. 